\title{
Tensions and transformations in developing the university professor in Dentistry: a cross-sectional study
}

\author{
Mariângela Monteiro de Melo Baltazar*; Carmen Célia Barradas Correia Bastos**; Renata Iani \\ Werneck $^{* * *}$; Marilisa Carneiro Leão Gabardo ${ }^{* * *}$; Simone Tetu Moysés ${ }^{* * *}$; Samuel Jorge Moysés ${ }^{* * *}$
}

* PhD, Department of Dentistry, Universidade do Oeste do Paraná

** PhD, Department of Pedagogy, Universidade do Oeste do Paraná

*** PhD, School of Life Sciences, Pontifícia Universidade Católica do Paraná

Recebido em 16/01/2016. Aprovado em 12/04/2017.

\begin{abstract}
This study aimed to evaluate the preparation of professors through university postgraduation programs, and try to learn the contradictions and possibilities of overcoming the problems that surround this formation. Also, to understand the dynamic process that encircles this activity, as well as the historical and current conjunctures of the university institution, for then discuss the profession in the ambit of Dentistry. Fifty-eight experts were invited to compose a specialists' panel. The Delphi Method was used, and the axes explored were: a) university and higher education models in Brazil; and $b$ ) formation and professional development of the university professor: teaching at higher education - formation of formers. Many inadequacies in the postgraduate formation were observed, with predomination of an instrumental preparation, with a low level of themes related to didacticpedagogical, political, and social aspects. Changes are necessary in the way of allowing advances in this practice which is essentially linked to the civilizing progress of societies.

Descriptors: Higher Education. Graduate Dental Education. University.
\end{abstract}

\section{INTRODUCTION}

In Brazil, the origin of high education courses happened later in relation to other European and American countries, beginning only in the 19th century ${ }^{1-3}$. At that time, the first isolated higher education units were the Surgery School of Bahia and Rio de Janeiro, in $1808^{4}$.

The first higher education formers in the country were professionals graduated in European universities, but, with the expansion of courses along the 20th century, there was the need to broaden the faculty. There was a searching for renowned professionals, with prestige and recognition in society. The way to join the professor career was, frequently, through an invitation made directly to the professional 
viewed as well succeeded in his professional technical practice, to ideally reply the formation of professionals as competent as he was ${ }^{1}$. The teaching work was distinguished and socially raised, being occupied by small contingents of the middle and high classes, even in public schools.

Nowadays, the growing offers of courses and programs by institutions, mainly in the private ones, occurs due to the political disclosing of access democratization, followed by the professors' proletarianization, which contributes to the process of lack of prestige of the profession, with repercussion on payment, and with control mechanisms over the practice, mainly referring to the quantitative aspects of intellectual production ${ }^{5}$.

Formally, the range of functions goes beyond the teaching classes ${ }^{6,7}$, in agreement with the primary role of the University that is to educate $^{8}$. However, even some convention formative functions, as having good knowledge of the subject, became complex with time, due to the exponential raising of scientific and technological knowledge, as well as the appearing of new working conditions.

For the university teaching, as well as for the university itself, the Lei das Diretrizes $e$ Bases da Educação Nacional - LDB (Directives and Bases of National Education), points to the indissolubility among teaching, research and extension (or services) ${ }^{6}$. This is translated into the production of knowledge as well as in its socialization, taking the future professional with a reflexive and questioning action of society's issues ${ }^{9}$. However, Rolindo ${ }^{10}$ reveals an existence of a mismatch between a requirement of the LDB and an indirect evaluation of the didactic training measured by the indicators instituted by the Ministry of Education.

Other dilemmatic issues permeate the higher education professor's acting in Brazil. Sometimes, the focus of priorities must be turned to research, at times to teaching, at times to the university extension, without, however, having the requested indissolubility. These dualities are verified by the frequent attempts in the curricular reformulation of graduation courses, including the discussion about the purpose of these courses, the search for alternative pedagogical models (or andragogical) ${ }^{11,12}$ for the teaching practice, and mainly by the necessary production and publishing of new kinds of knowledge ${ }^{12,13}$.

Based on previous considerations, this paper aimed to question the preparation of professors through university postgraduation programs and to learn the contradictions and problems that enclose the profession, considering the formation of stricto sensu postgraduation in Dentistry in Brazil.

\section{MATERIAL AND METHODS}

With a qualitative-quantitative designed, we composed an authority panel, using the electronic Delphi method (e-Delphi) ${ }^{14}$. For this, questionnaires were available electronically on a site for the rounds.

The questions were referred to the axes: a) university and higher education models in Brazil; and $b$ ) formation and professional development of the university professor: teaching at higher education - formation of formers.

Fifty-eight researchers were invited. When the participation of the legal representative initially related was not possible, another likely participant was indicated, so all the segments were represented with at least one research subject. Effectively, 30 subjects took part in the first round; 24 in the second, and 19 in the third and last round.

The segments related as panel participants were: higher education professors in postgraduation in Brazil: Ministry of Education; Coordenação de Aperfeiçoamento de Pessoal de Nivel Superior - CAPES's (Coordination of Improvement of Higher Education Personnel); Conselho Nacional de Desenvolvimento Científico e Tecnológico - CNPq (National Council of Scientific and Technological Development) (3 subjects); National Level Health Administrators; Ministry of Health/Administration Department in Health Work (3 subjects); Representative body of postgraduation in Brazil: Pro-deans of research and postgraduation Forum (1 subject); Representative body of postgraduation in 
Dentistry: Sociedade Brasileira de Pesquisa Odontológica - SBPqO (Brazilian Society of Dental Research) (3 subjects); Representative body of the Brazilian Dental Teaching: Associação Brasileira de Ensino Odontológico ABENO (Brazilian Association of Dental Education) (1 subject); Representative body of postgraduation in Collective Health: Associação Brasileira de Saúde Coletiva - ABRASCO (Brazilian Association of Collective Health) (4 subjects); Representative bodies of Dentistry: Associação Brasileira de Odontologia - ABO (Brazilian Dental Association); Associação Brasileira de Cirurgiões-Dentistas - ABCD (Brazilian Association of Dental Surgeons) (2 subjects); Academical Authorities of dental postgraduation in Brazil: Coordinators of stricto sensu postgraduation programs, representing different regions of Brazil - Southwest, South and Northeast (3 subjects) - the chosen Programs were the ones with higher grade in each region. Those who accepted to participate were part of the study; Renowned scholars in the thematic "Human Resources in Health" in Brazil, based on the Lattes curriculum, and respective fields of study and publications: 10 subjects, one being from the education field, two from the medical field, and seven from Dentistry.

Also, a search in specialized literature in the thematic of university professors' formation, postgraduation stricto sensu in Dentistry, health, and educational policies was done. The documents from the Coordenação de Aperfeiçoamento de Pessoal de Nível Superior CAPES' (Coordination of Improvement of Higher Education Personnel) were consulted, as National Postgraduation Plan 2005-2010 ${ }^{15}$, and Indicator Notebooks for the dental area of $2009^{15}$. This was studied to identify subjects with didactic-pedagogical contents, as well as research lines that contemplated this thematic. Some selection criteria were created so that such analysis was possible to be made. Starting from a 93 stricto sensu dentistry postgraduation program universe (master and/or doctorate) in Brazil, among academic and professionalizing, those whose CAPES concept was equal to or higher than 5 , and that had master and doctorate academicals, which lead to a total of 24 programs. Such criteria were based on the premise that the assumption must mean that such programs express their quality for being mature, consolidated, with high performance in knowledge production and being nucleated and structuring for the area, as well as representing ideal examples for new programs that yearn such concepts.

Still, in the document cited above, the subjects whose content was pertinent to the formation of the higher education dentistry lecturer were researched. A detailed reading was carried out on the memorandums, programmatic contents and subject recommended bibliography. The following categorizing was made.

a) Advanced didactical-pedagogical concept (APC): very well detailed memorandum as to the historical and conceptual aspects of university and post-graduation, with the content of the higher education policies, concepts of pedagogy (andragogy) ${ }^{11}$ of the higher education as well as of didactics. Recommended references that are current and pertinent to the thematic; programmatic content that is relevant to the memorandum. In this category, the program that fit all the items was framed.

b) Incipient or intermediate didacticpedagogical conception (IPC): very well detailed memorandum as to the historical and conceptual aspects of university and post-graduation, with the content of the higher education policies, concepts of pedagogy (andragogy) of the higher education as well as of didactics. Recommended references that are current and pertinent to the thematic. Programmatic content that is pertinent to the memorandum. In this category, the program that fit at least two of these aspects, without, however, fitting them integrally was framed.

c) Instrumental conception (IC): little detailed memorandum referring to the instrumental aspect of teaching planning composition, class preparation, and usage of multi-means resources. Bibliographic 
references little pertinent to the thematic. It was put into this category when one or more items were present with absence of the previous category items.

Then, the first questionnaire model was structured, which went through a first evaluation of form and content with thematic scholars in the State of Paraná and some adjustments were made to refine the comprehension of the questions, followed by a simple statistical feedback to the participants' panel, which has involved the devolution, in each round, of the distributions and frequency of the answers for each item ${ }^{17}$.

Three rounds have been realized, and the questions have been considered stabilized when a percentile equal to or above $75 \%$ of agreement among the responsive has been reached in each one of them or when the sum of similar options reached that percentage after the second round. On the third round, only the questions that did not reach $75 \%$ of isolated agreement or the sum of the similarities on the previous rounds were submitted.

The content of the comments was analyzed by Bardin's methodology ${ }^{18}$. A category tree was elaborated by their thorough reading, meaning that the most relevant aspects of the study were highlighted, and each category was grouped.

The research was approved by the Committee on Ethics in Research of Pontifícia Universidade Católica do Paraná, under register n. ${ }^{\circ} 0003542 / 09$. The Consent Form was available to be read by the research participants and later acceptance.

\section{RESULTS}

A loss of 11 research subjects occurred during the rounds, which corresponds to $36.6 \%$. The synthesis of the questions, the percentile of stabilization, and in which round they were stabilized are presented in table 1.

There was $82 \%$ agreement reached by the participants, about the structure of organization of higher education in Brazil, which privileges, significantly, the instrumental domain of knowledge and professional technical competencies to develop the teaching practice. Also, $78.3 \%(69,5 \%$ little and $8,7 \%$ does not guarantee) of the researched affirmed that the scientific production, with respective publications, are not enough to ensure the quality of university teaching, with stabilization in the second round.

For $85.7 \%$ of the specialists (stabilized in the second round) agree that the Dentistry stricto sensu postgraduation has contemplated the pedagogical domains as "little" adequate.

The panorama of postgraduation in Dentistry was considered "very" or "totally worrying" for $95 \%$ of the respondents $(67,5 \%$ very worrisome and $28,5 \%$ totally worrisome) referring to the contents of formation of the higher education professor. Also, 91\% considered as "very important" $(68,18 \%)$ or "totally important" $(28,5 \%)$ the offer of these contents as mandatory and with a critical review of their strategies and approaches.

When the raised topic was teaching internship, mandatory for CAPES scholarship holders since 2000, and adopted for all the students by many postgraduation programs, $77 \%$ of the specialists understood that they are "very" or "totally" adequate strategies to the formation of the professor in Dentistry, and 23\% think that they are "little" adequate.

About the political formation of the university professor, $100 \%$ of the specialists understood that, for teaching, they must have political dominions.

\section{DISCUSSION}

The Delphi Method applied allows a group of individuals to deal with complex matters ${ }^{14}$. It was chosen because is specially used to obtain opinion and judgment consensus or the choice to determine, foresee and explore group attitudes, needs and priorities from a specialists' panel ${ }^{19,20}$, and keeping the anonymity ${ }^{14}$.

This method's positive points consist in the fact that anonymity guarantees the freedom and absence of any constraint. Moreover, there was no actual meeting of the responsive, reducing the influence of psychological factors, as for example, the effects of persuasion capacity, the reluctance in abandoning taken positions, and the dominance of majority groups in relation to 
minority groups. This method does not use a random representative sample of the population, and this can be considered a methodological limitation, however, by using "experts", it acquires higher potency over the understanding of the studied problem, as each responsive to the questionnaire is a specialist in the area in which the investigator is interested $\mathrm{in}^{17}$.
The subjects chosen represented the related segments in the method or indicated by their representatives, as well as scholars of the human resources in health and Dentistry formation thematic; and higher education and so, obtaining a broad specter of opinions about the examined questions, avoiding that the composing of the panel introduced personal bias over the obtained results ${ }^{21}$.

Table 1 - Synthesis of the thematic issues approached in this article, percentages, and stabilization round.

\begin{tabular}{|c|c|c|c|}
\hline Thematic approached the issue & 1st round & 2nd round & 3rd round \\
\hline $\begin{array}{l}\text { The organization structure of higher education in Brazil } \\
\text { has privileged the domain of professional experiences and } \\
\text { knowledge such as requisites for a teacher in higher } \\
\text { education courses. }\end{array}$ & $\begin{array}{l}45 \% \text { partially } \\
\text { agrees }\end{array}$ & $\begin{array}{l}43 \% \text { partially } \\
\text { agrees, and } 39 \% \\
\text { totally agrees }\end{array}$ & \\
\hline $\begin{array}{l}\text { It is known that Stricto Sensu Post-Graduations in Brazil, } \\
\text { in a general way and, especially in Dentistry, has } \\
\text { successively tried to develop the necessary competencies } \\
\text { for the research activity and scientific production, with } \\
\text { respective publications. Does this guarantee the quality in } \\
\text { the higher education teaching practice? }\end{array}$ & $\begin{array}{l}60 \% \text { guarantee } \\
\text { little }\end{array}$ & $\begin{array}{c}69,5 \% \text { little and } \\
8,7 \% \text { doesn't } \\
\text { guarantee }\end{array}$ & \\
\hline $\begin{array}{l}\text { The conception of teaching formation in the higher } \\
\text { education present in most of the memorandums of the } \\
\text { Dentistry Stricto Sensu Post-Graduations in Brazil is } \\
\text { related to the field of the instrumental domain, of didactic } \\
\text { material confection, pictures, informatics for preparing the } \\
\text { class, strategies for theoretical teaching and evaluation. }\end{array}$ & $\begin{array}{l}46 \% \text { partially } \\
\text { agrees }\end{array}$ & $\begin{array}{l}67 \% \text { partially } \\
\text { agrees, and } \\
28,5 \% \text { totally } \\
\text { agrees }\end{array}$ & \\
\hline $\begin{array}{l}\text { In the disciplines/domains and respective memorandums } \\
\text { related to the didactical-pedagogical formation in the } \\
\text { Dentistry Stricto Sensu Post-Graduations in Brazil (with } \\
\text { CAPES evaluation above 5), it has been realized that they } \\
\text { are used to being optative and strictly instrumental. Even } \\
\text { considerating that the obligation does not guarantee the } \\
\text { quality of formation, do you consider this question? }\end{array}$ & $\begin{array}{l}57 \% \text { very } \\
\text { worrisome }\end{array}$ & $\begin{array}{l}67 \% \text { very } \\
\text { worrisome and } \\
28,5 \% \text { totally } \\
\text { worrisome. }\end{array}$ & \\
\hline $\begin{array}{l}\text { About the importance of offering the discipline/domain } \\
\text { related to the didactical-pedagogical formation in the } \\
\text { Dentistry Stricto Sensu Post-Graduations in Brazil, in an } \\
\text { obliged aspect and with a critical review of its content and } \\
\text { pedagogical strategies. }\end{array}$ & $\begin{array}{l}55 \% \text { very } \\
\text { important }\end{array}$ & $\begin{array}{l}68,18 \% \text { very } \\
\text { important and } \\
22,73 \% \text { totally } \\
\text { important }\end{array}$ & \\
\hline $\begin{array}{l}\text { Are the Teaching Internships in which master and } \\
\text { doctorate students live the graduation classes, obligatory } \\
\text { for CAPES scholarship holders and very much used by the } \\
\text { majority of Stricto Sensu Post-Graduations in Dentistry, } \\
\text { strategies that effectively contribute to the formation of the } \\
\text { Dentistry Professor? }\end{array}$ & $\begin{array}{l}\text { Question added } \\
\text { to the second } \\
\text { round by } \\
\text { specialist's } \\
\text { suggestion. }\end{array}$ & $\begin{array}{l}50 \% \text { very } \\
\text { important }\end{array}$ & $\begin{array}{l}74 \% \text { very } \\
\text { important } \\
\text { and } 5 \% \\
\text { totally } \\
\text { important }\end{array}$ \\
\hline $\begin{array}{l}\text { For his university teaching practice, must the professor } \\
\text { also have the domain of the political dimension? }\end{array}$ & $55 \%$ totally & $\begin{array}{l}61 \% \text { totally, and } \\
39 \% \text { a lot }\end{array}$ & \\
\hline
\end{tabular}

Also, when elaborating the questions, although there are no strict manners when it comes to formatting, it is relevant to avoid redundancy, for this could make the experts lose 
motivation or waste too much time in answering them. This posture search to avoid ambiguous considerations, making the questionnaire simple to be answered ${ }^{21}$. Traditionally, Delphi is carried out through conventional mail, but with the advances and readiness enabled by the broad use of the Internet, the electronic form was elected ${ }^{22}$. Recently, the method was used to build consensus among dental faculty members and students $^{23}$.

Regarding the thematic searched, the experts and the literature have pointed that the structure of Brazilian higher education, with the prevalence of technical aspects, reinforces, at stricto sensu postgraduation, the development of competencies for the research activity and scientific production, with respective publications ${ }^{7,13,24-26}$

Masetto $^{25}$ highlights that the professors are still recruited due to the increasing demands of titles at the master or doctorate levels, understanding that this will make them more competent in communicating knowledge that is pertinent to their area of practice. From them, however, professional competencies as professors/educators are not demanded, related to the pedagogical and political-social dimensions. The function seems to remain to be the one of a "classer" (that gives classes) that comes to "minister" to the ones who do not know $^{27}$.

For Veiga $^{9}$ teaching requires professional formation for his practice and forming university professors implies understanding teaching's important role, when propitiating scientificpedagogical depth and making them capable of facing fundamental university issues as a social institution and social practice that comes from the ideas originated from the trinomial formation, reflection, and critique.

The results of the LDB about university professors' formation are very shy. In this document, in the 66th article, the formation must occur, priority, in master and doctorate programs $^{6}$. It is appropriate to highlight that the postgraduation programs have turned themselves to the formation of researchers in their specific fields and not demanding anything as to professor pedagogical formation ${ }^{9,25,28,29}$. The professor formation for higher education is considered a responsibility of the individual initiatives and regulations of the institutions responsible ${ }^{9}$. Regarding the quality of education, a study revealed that most lecturers are not adequately trained to be effective lecturers ${ }^{30}$.

Pimenta et al. $^{31}$ cited that, at the stricto sensu programs, in general, this preparation has been occurring by means of a subject from 45 to 60 hours, with different characteristics and denominations. Although this schedule is small, it has enabled some form of pedagogical growing to the professors of higher education. However, it is necessary to consider the exiguity of this time to form any professional, including the professionalization for teaching at the university.

In the 24 stricto sensu postgraduation programs in Dentistry, indicated by CAPES ${ }^{16}$, are presented with a concept equal to or above 5 , were found subjects related to the didacticalpedagogical contents with different denominations and with a schedule that varies from 30 to 450 hours. It has also been observed that there are very few research lines with this thematic. One program has presented a research line compatible to the development of educational research by the students, and two with isolated research projects. Another program, even being for improving clinical skills, has presented subjects that deal with higher education, educational policies content (with 45 hours), and another subject, with 45 hours, dealing with the teaching and research social responsibility content. Just the referred program mentioned the LDB for Dentistry course as an object of analyses and practice. Such findings allow thinking that the political-pedagogical and teaching contents of the programs depend more on located regulations and innovative group processes, more singular, than programmatic arrangements and developing broader institutional policies that regulate these enterprises.

Another question to be considered is that three programs have advanced in didacticalpedagogical conceptions; eight programs were incipient or intermediate in this aspect; twenty 
programs had a mere instrumental conception, and one not even was mentioned to the contents of teaching formation.

Regarding the teaching internship, which was considered an adequate strategy in the postgraduation programs for most of the participants, this study points out that inserting internship without a necessary reflection about this may reaffirm the current teaching model, centered on the professor, with the exclusive domains of his area and on the not contextualized forward of these kinds of knowledge, distant from the needs and expectations of society. It is still important to emphasize that being mandatory only for CAPES scholarship holders does not fulfill the majority of vacancies in many stricto sensu postgraduation programs, for the fomentation through scholarships is still small and, thus, excluding a considerable contingent of possible higher education professors. The offer of internship for professors by the programs must take into account the professors' activities that, according to $\mathrm{Zabalza}^{7}$ are not restricted to the classroom, passing through administrative and researching activities. Thus, such internships must consider the importance of learning the kinds of knowledge related to how the higher education institution works, also its institutional political project, of educational policies for higher education as well as the historical process of its construction and the theories that built them.

Is there also space for the reflection on the evaluation process of these internships? Are there guiding parameters of its offer? Which are the learning guarantees of the necessary pedagogical knowledge by the post-graduated? Does CAPES have an evaluation of this policy in qualitative terms? Such questions can be the object of analyses in future studies. Brazilian researchers agreed that changes are needed in program assessment system of teacher training ${ }^{32}$.

It is necessary to point out the continuous character that the professors' formation must undertake, not end, however, passing by the stricto sensu programs but, having the university taking over the institutional responsibility of permanently forming its faculty, concretizing the minutes of the 1999 National Graduation Plan ${ }^{33}$.

About the dimension of political formation of the university professor, it is important to understand that they, at many moments of his professional trajectory, comes upon institutional politics formulations that elapse from the conflicting political world and power correlations, either at his course council, or as a legal representant of the many university instances, and its relation to society. In all these moments, anxieties, visions of the world, beliefs systems, and political positioning that are required and important, emerge.

\section{CONCLUSION}

There is a consensual and growing concern among the specialists that represent stricto sensu postgraduation, as to the university's directions and professors' forming. There is a connotation that the programs are directed at training researchers/publishers of technical expertise. It was evidenced that the professors' knowledge is limited to instrumental knowledge, abdicated of its political condition, under the dependence of private wills that become institutional, suppressing the political learning, the socially responsible learning, the pedagogical, historical and epistemological from his practice.

The teaching practices in all its dimensions are it at graduation and post-graduation teaching, research, extension, administration, and all these to their larger relations with society and its period must recognize the real power of university, able of changing all of this for the general welfare.

\section{RESUMO}

\section{Tensões e transformações no desenvolvimento do professor universitário em Odontologia: um estudo transversal}

Este estudo teve como objetivo avaliar a formação de professores por meio de programas de pós-graduação universitária e tentar conhecer as contradições e possibilidades de superação dos problemas que envolvem esta formação. Além disso, compreender o processo dinâmico que circunda esta atividade, bem como as conjunturas históricas e atuais da instituição universitária, para então discutir a profissão no âmbito da 
Odontologia. Cinquenta e oito especialistas foram convidados a compor um painel. O Método Delphi foi utilizado e os eixos explorados foram: a) modelos universitários e de ensino superior no Brasil; e b) formação e desenvolvimento profissional do professor universitário: ensino em nível superior formação de formadores. Foram observadas muitas inadequações na formação de pósgraduação, com predomínio de uma preparação instrumental, com um baixo nível de temas relacionados aos aspectos didático-pedagógico, político e social. São necessárias mudanças no sentido de permitir avanços nesta prática que está essencialmente ligada ao progresso civilizador das sociedades.

Descritores: Ensino Superior. Educação de PósGraduação em Odontologia. Universidade

\section{REFERENCES}

1. Masetto MT. Docência na Universidade. Campinas: Papirus; 1998.

2. Chaui M. A universidade pública sob nova perspectiva. Rev Bras Educ. 2003;24:5-15.

3. Almeida-Filho N. Universidade nova: textos críticos e esperançosos. Salvador: EDUFBA; 2007.

4. Saliba NA, Moimaz SA, Garbin CA, Diniz DG. Dentistry in Brazil: its history and current trends. J Dent Educ. 2009;73(2):22531.

5. Cunha MI. Reflexões e práticas em Pedagogia universitária. Campinas: Papirus; 2007.

6. Lei n. 9.394, de 20 de dezembro de 1996. Estabelece as diretrizes e bases da educação nacional. [Cited 02 Dec. 2016]. Available from: http://www.planalto.gov. br/ccivil 03/leis/L9394.htm

7. Zabalza MA. O ensino universitário: seu cenário e seus protagonistas. Porto Alegre: Artmed; 2004.

8. Lenartowicz M. The nature of the university. High Educ. 2015;69(6):947-61.

9. Veiga IPA. Docência Universitária na Educação Superior. In Ristoff D, Sevegnani $\mathrm{P}$, editors. Docência na Educação Superior.
Brasília: Instituto Nacional de Estudos e Pesquisas Educacionais Anísio Teixeira; 2006. p. 85-96.

10. Rolindo JMR. Descompasso entre a exigência de formação didático-pedagógia para a docência universitária na LDB 9.394/96 e o processo de avaliação institucional. Rev Educ. 2007;10(10):75-9.

11. Behar-Horenstein LS, Schneider-Mitchell G, Graff R. Promoting the teaching of critical thinking skills through faculty development. J Dent Educ. 2009,73(6):66575.

12. Secco LG, Pereira MLT. A profissionalização docente e os desafios político-estruturais dos formadores em Odontologia. Rev ABENO. 2004;4(1):22-8.

13. Chamlian HC. Docência na universidade: professores inovadores na USP. Cad Pesqui. 2003;118:41-64.

14. Linstone HA, Turoff M, editors. The Delphi Method. Techniques and applications. [Cited 29 Nov. 2016]. Available from: http://is.njit.edu/pubs/ delphibook/

15. Brasil. Ministério da Educação. Coordenação de Aperfeiçoamento de Pessoal de Nível Superior. CAPES: Plano Nacional de Pós-graduação 2005-2010. Brasília: CAPES; 2004.

16. Brasil. Ministério da Educação. Coordenação de Aperfeiçoamento de Pessoal de Nível Superior. CAPES. Cadernos de indicadores. [Cited 29 Nov. 2016]. Available from: http://conteudoweb. capes.gov.br/conteudoweb/CadernoAvaliac aoServlet?acao=pesquisaAno\&ano=2009

17. Lima MO, Pinsky D, Ikeda AA. A utilização do Delphi em pesquisas acadêmicas em administração: um estudo nos Anais do EnAnpad. [Cited 29 Nov. 2016]. Available from: http://www.ead.fea.usp. br/semead/ 11semead/resultado/trabalhosPDF/535.pdf

18. Bardin L. Análise de conteúdo. Lisboa: Edições 70; 1977.

19. Piola SF, Vianna SM, Vivas-Consuelo D. Delphi Study: social actors and trends in the Brazilian health care system. Cad Saude Publica. 2002;18 Suppl:S181-S90. 
20. Tonni I, Oliver R. A Delphi approach to define learning outcomes and assessment. Eur J Dent Educ. 2013;17(1):e173-80.

21. Wrigth JTC, Giovinazzo RA. Delphi: uma ferramenta de apoio ao planejamento prospectivo. Cad Pesqui Adm. 2000,1(12):54-65.

22. Cole ZD, Donohoe HM, Stellefson ML. Internet-based Delphi research: case based discussion. Environ Manage. 2013;51 (3):511-23.

23. Best L, Walton JN, Walker J, von Bergmann H. Reaching consensus on essential biomedical science learning objectives in a dental curriculum. J Dent Educ. 2016;80(4) :422-9.

24. Cunha MI. Ensino com pesquisa: a prática do professor universitário. Cad Pesq. 1996;97:31-46.

25. Masetto MT. Competência pedagógica do professor universitário. São Paulo: Summus; 2003.

26. Bastos CCBC. Docência, pós-graduação e a melhoria do ensino na universidade: uma relação necessária. Educere et Educare. 2007;2(4):103-12.

27. Arroyo MG. Ofício de Mestre: imagens e autoimagens. Petrópolis: Vozes; 2010.

28. Giolo J. Os docentes da educação superior brasileira. In: Ristoff D, Sevegnani P, editors. Docência na Educação Superior. Brasília: Instituto Nacional de Estudos e Pesquisas Educacionais Anísio Teixeira; 2006. p.19-46.
29. Haddad AE, Peres MA, Morita MC, Oppermann RV, Moysés SJ. Pesquisa odontológica no Brasil e sua articulação com as políticas públicas de saúde. Revista Espaço para a Saúde. 2008;9(2):47-53.

30. Mahat A, Bezruchka SA, Gonzales V, Connell FA. Assessment of graduate public health education in Nepal and perceived needs of faculty and students. Hum Resour Health. 2013;11:16.

31. Pimenta SG, Anastasiou LGC, Cavallet VJ. Docência no ensino superior: construindo caminhos. In Barbosa RLL, editors. Formação de Educadores: desafios e perspectivas. São Paulo: UNESP; 2003. p. 267-89.

32. Baltazar MMM, Moysés SJ, Bastos CCBC. Profissão, docente de odontologia: o desafio da pós-graduação na formação de professores. Trab educ saude. 2010;8 (2):285-303.

33. Brasil. Plano Nacional de Graduação: um projeto em construção. Fórum Nacional do Pró-reitores de Graduação das Universidades Brasileiras - Forgrad; 1999.

Corresponding author:

Marilisa Carneiro Leão Gabardo

e-mail: marilisa.gabardo@pucpr.br

Rua Imaculada Conceição, 1155

80215-901, Curitiba/PR 